\title{
Technocracy and Democracy: The Challenges to Development in Africa
}

\author{
Francis E. Owakah \\ Department of Philosophy and Religious Studies \\ University of Nairobi, Kenya \\ fowakah@yahoo.com \\ and \\ Robert D. Aswani \\ Ministry of Immigration \\ Nairobi, Kenya \\ ranaswa@yahoo.com \\ Thought and Practice: A Journal of the Philosophical Association of Kenya (PAK) \\ Premier Issue, New Series, Vol.1 No.1, June 2009, pp.87-99 \\ thoughtandpractice@uonbi.ac.ke OR thoughtandpractice@gmail.com
}

\begin{abstract}
In this paper, we argue that the future of development in Africa lies in the shift from democracy in the conventional sense to technocracy, where the role of the expert is recognized and appreciated. We set out by presenting conceptualizations of democracy and technocracy. Thereafter, we highlight the challenge posed by the demands of the information society to traditional concepts of democracy.
\end{abstract}

\section{Introduction}

Democracy is a system of governance in which political leaders are freely elected, with the underlying assumption that the leadership will be responsible to the governed by translating pre-election pledges into concrete policies that enhance the general welfare of society. However, the elected leaders rely on experts to formulate and implement the relevant policies. Such technocrats therefore exercise authority and 
power by virtue of their competence in specific fields. Thus the technocrat exercises influence on the political leader, who in turn takes credit for the benefits that accrue to society.

In this paper, we argue that the future of development in Africa lies in the shift from democracy in the conventional sense to technocracy, where the role of the expert is recognized and appreciated. We set out by presenting conceptualizations of democracy and technocracy. Thereafter, we highlight the challenge posed by the demands of the information society to traditional concepts of democracy.

\section{Conceptualising Technocracy and Democracy}

\section{Technocracy}

The term "Technocracy" was first used by Smyth (1919). Smyth's usage referred purely to Industrial democracy, in which he sought to demonstrate the integration of 'workers into decision making through existing firms or revolution'. Later the term came to mean government by specialized decision making. A technocratic government is a system of experts designed to ensure administrative functions are carried out efficiently (Wikipedia 2009).

Technocrats are individuals with specialized training, who approach societal problems from the vantage point of appropriate knowledge and experience. They seek solutions to problems in science and technology broadly conceived. According to Njalsson (2006), 'technocrats are primarily driven by their cognitive "problem-solution mindsets", and only in part by particular occupational group interests. The activities of technocrat's and the increasing success of their ideas are thought to be a crucial factor behind the modern spread of technology and the largely ideological concept of the "Information Society"'.

A technocracy thus describes a situation or society in which those who govern justify themselves by appeal to expertise in scientific forms of knowledge. In 
contradistinction to democracy, technocracy is a system in which decision makers are selected on the basis of the knowledge they demonstrate, rather than how much political capital they hold or how popular they are. One can easily characterize some forms of technocracy as elitism, whereby the "most qualified" and the administrative elite tend to be the same (Rose 2006; Golden 2006). Overall, a technocracy relies more on expertise and leadership skills selected through bureaucratic processes rather than democratic elections.

According to Hubbert(1974) and Howard (2005), technocracy irreducibly displays the following features:

- Laws and regulations are designed to pay attention to performance and efficiency, not individuals.

- Laws are enforced by designing a system such that it is impossible to break them.

- The various 'branches of the government work together and share knowledge to maximize the performance of each branch in as equal a way as is feasible'.

- Only experts occupy positions where crucial decisions are to be made in the bureaucracy, so that, for a few instances, the economy is regulated by economists; Social policy is designed by political scientists; the health care system is run by medical professionals.

The above framework may seem authoritarian, but the principles of a technocracy should be anticipatory - designed as a form of in-built problem-solving, in which action is based on the psychology of conditioning, rather than on the intrusive whims of personality. Such an approach to handling complex issues allows for a reasonable division of roles as follows:

- Experts provide understanding of the dynamics, facts and stakes involved.

- Citizens provide the values, every-day issues, and common sense suggestions.

- Consequently, experts prepare policy recommendations. 
Broadly speaking, then, a technocracy is governance by those who have reached the pinnacle of their fields of specialization. Thus a technocracy should infuse a logistical approach to societal challenges.

\section{Democracy}

Democracy is a form of government in which the supreme power is held by the people under a free electoral system (Dunn 1994; Kurt 2007). Democracies function within the framework of two related principles, namely, (1) all members of the society have equal access to power, and (2) all members enjoy universally recognized freedoms and liberties.

There is a variety of democracies, some of which provide better representation and more freedoms for their citizens than others. However, if any democracy is not carefully designed to avoid an uneven distribution of political power, a branch of the system accumulates power in a way that is harmful to democracy itself. The " majority rule" is often described as a characteristic feature of democracy, but without responsible government it is possible for the rights of a minority to be abused by the "tyranny of the majority". An essential process in a representative democracy is competitive election, that is fair both substantively and procedurally. Furthermore, freedom of political expression, freedom of speech and freedom of the press are essential, so that citizens are informed and able to vote in their personal interests. In short, popular participation and respect for human rights have long been central components of nations that subscribe to the democratic ideal. With these principles in mind, a democracy seeks to achieve the following:

- The promotion of individual and social liberties, security, stability, and prosperity.

- The upholding of participatory principles and structures.

- Identification and denunciation of internal institutions that deny their members the right to choose their leadership in a free, fair, and transparent manner. 
These are weighty matters requiring careful crafting, necessitating the input of technocrats in a democracy. Although popular sovereignty may exist, its evaluation and veracity may be an uphill task.

In many countries, democracy is based on the philosophical principle of equal rights. Extrapolating this discourse then, the term "democracy" connotes political pluralism, equality before the law, the right to petition elected officials for redress of grievances, due process, civil liberties, human rights, and elements of civil society outside the government (Dahl 1989). By implication, in a democracy, popularly elected persons make decisions that ordinarily should be left to experts. Wanyande (1987) avers that in a democratic system, the political leader is elected to office partly because of the election pledges he makes. Once in office, the politician has a challenge of transforming the pledges into action. A politician's mandate is not based on knowledge, skills or performances. In essence, an election brings on board both experts and non-experts. The challenge is that the politician will be evaluated by the electorate on the basis of how well he/she translates his/her pledges into action. The flipside is a thorough examination of what role specialized knowledge ought to play in leadership, given that the society is so complex that solutions to its problems require multiple threads of expertise.

If the aim is to create a future most desired by the people, effective leadership must move from conscious belief based decision making to value-based decision making. The fundamental question to be asked in this regard is, "when a decision is being taken, is it aligned with the values represented by the government and the democratic aspirations of the people?" If the decision were to be rational but not in concurrence with such values, it would not be consistent with the objective of growth and development.

In our view, democracy, just like all other forms of governance, is not a clean, theoretical concept applied to reality, but a process that has evolved. Democracy in its modern sense is traceable to different facets associated with the social development of Europe. It is possible to see the link between the evolution of democracy and the secularization of Europe that took place in the 17th and 18th centuries. One can begin by citing the Medieval separation of power between the Church and State, through the 
works of philosophers such as Locke and Voltaire who proposed a constitutional division of power between the king and parliament in which the subjects had absolute rights to life, liberty and property, to Montesquieu, another French philosopher, who proposed a system where power was divided into three, namely, the legislature, executive and judiciary.

For a number of reasons, the above models of governance are not pure democracies in the strict sense. First, they are based on constitutions which limit the scope of governance within a specific social consensus. Second, they are based on representation, not direct participation, so that the citizen does not play a significant role in rowing the boat of decision making. Third, they merely respond to existing laws and regulations, which do not necessarily nurture an environment conducive to the making of sound decisions. For example, many investment decisions are politically driven due to their popular appeal, rather than their ability to generate quality life for the citizens. Even worse for the newly independent African countries, their constitutions were designed by colonial masters, who wanted particular forms of governance to thrive for the colonialists' own interests. Demand for review of these constitutions has not been easily entertained, because radical constitutional reforms are bound to destabilize the balance of power at the economic front. Forth, there is a social stratum of civil servants organized in a bureaucracy - a class that is supposed to be based on professionalism and expert knowledge - but their own interests and those of the political leadership frequently override the pursuit of the true common good.

In its pure form, democracy is the most impracticable of systems. To appreciate this, one only needs to look at ancient Athens where every day, about five thousand men met at the main square to deliberate on all issues including but not limited to war and peace, the budget, the laws, kinds of punishment, property and life. Such a system cannot allocate resources rationally, because it lacks the requisite expertise to do so. It actually misallocates resources depending on the prevailing political interests. So what is the way out for Africa?

When addressing citizens, many African presidents assume that they hold the solutions to all the problems bedeviling society. Such presidents often forget that a ruler is only a temporary trustee, and not the owner of the people's future. This is the 
folly of democracy - that the ruler's vision is based upon and defines proposals and suggestions made by millions of the country's citizens. Consequently, what the leader does is to simply articulate the collective wishes of the people, whether he believes in that vision or not. Thus Africa's current political leaders frequently make the following debatable claims:

- That the citizens should join the leaders in a united and concerted effort at bringing material advancement.

- That governance as currently practiced in Africa is a value-driven liberal democracy.

- That when the leaders speak of material advancement and well-being, they refer to the overall elevation of the living standards of the citizenry.

\section{Expertise and Citizenship: The Challenge to Democracy}

The ideal of democracy is that citizens make decisions that affect their own lives. However, governance is so complex that a mere vote cannot decide on the suitability or otherwise of a particular policy. So, would we know what to do with the government if we took control of it? Take the post election violence in Kenya for example, where the youth unleashed violence, leading to rampant anarchy, including the loss of many lives. Yet in spite of the violence, Kenya was still a sovereign state, dealing with issues of foreign relations. This Kenyan experience provides an illustration of the indispensable role of the expert in a democracy.

Most African countries still struggle with the tripartite problems that are aptly captured by the United Nations Millennium Development Goals: Eradication of poverty, Provision of adequate health care, and universal provision of education. These problems can be given a solution based perspective if and only if they are well conceived in a technocratic system embedded in a value-driven democracy. Out of this, a country can address ways and means of investing in roads, power, water, sanitation, health care and education by identifying the basic needs of the populace, computing the cost of meeting them, and identifying ways of financing the relevant 
services. The amount of public resources wasted in Africa points to the lack of expert management of public affairs.

Sachs (2005) contends that poverty in itself is a trap, such that those already in it have no way of climbing out of it by their own effort, so that others who are able to help the poor need to do so. This is true for many in Africa: They are poor because they are poor. They cannot develop because they lack resources necessary for development. Most of the development aid is appropriated by the rich. However, as an expert, Sachs advises that the elimination of poverty is a real possibility within the lifetime of the current generation of youth. What many leaders in Africa forget is that economic development is a systemic process. It is not possible to pinpoint what part of an economy requires most urgent attention without clear knowledge of how the system as a whole works. A value-based democracy ought to be managed by people who appreciate that development is not merely concerned with material well being, but also covers in a broad sense all forms of human progress. Thus the development brought about by a genuine democracy would not be measured merely by the increased per capita income of the citizens of a country, but also by their political and economic freedom and their equal enjoyment of the fruits of growth. Honest democracy means the ability by the political leadership to recognize their limitations, and to invite experts to perform important tasks in society, without feeling slighted.

The foregoing observations do not indicate that democracy is worthless, but that there is no evidence to suggest that it is a precondition for economic growth. The claim that democracy supports stability and sustains fair distribution of goods and services is not supported by empirical evidence. A number of less developed countries have disapproved it. Malaysia under Mahathir Mohamed serves as a case in point. Economic prosperity took place within a framework of anything but democracy. It is evident that both democracy and development denote a continuous change brought about over a sustained period of time through deliberate efforts. In both cases however, the role of the expert cannot be downplayed.

Wallace (2007) argues that the concept of technocracy can be defined as "rule by skill". In this definition, Wallace likens technocracy to a platonic meritocracy of the skilled. This analysis to some, rightly or otherwise, implies that technocrats are anti- 
democratic. However, a democracy may be effectively driven by the work and influence of technocrats. One must bear in mind that the knowledge attributed to technocrats need not necessarily relate only to hard sciences, as is usually assumed. The need for a technocracy within the overall parameters of a democracy stands on the fundamental premise that democracy is rule by the people, who might not always be able to grasp the complexities of a modern world, which in turn calls for experts to address intricate issues facing a nation.

Alford and Friedland (1990, 175), commenting on the transition from industrial to post industrial society, hold that due to the growing organizational complexity of the society, there is need for both corporate and state planning by the technocrat. This in essence means that the politician has to seek the assistance of the technocrat in realizing societal goals. In the conceptual development of a technocracy, the expert is an indispensable administrative staff in a political system (Bell 1973, 364; Agarwal et. al. 1993, 293). The technocrat is the man or woman equipped with specialized knowledge - conceptual tools with which to look at the bigger picture, something that often bypasses the politician (Weinberg 1977, 22-30). On the one hand, the technocrat sees no interest but values, performance and goals. He/she is a behind-the-scenes yet powerful assistants. On the other hand, the politician thrives on playing to the gallery.

The manner in which the politician relates to the technocrat in the course of turning the election pledges into policies and programs for development is a matter that interests a number of political theorists. Mugyenyi $(1987,158)$ contends that politicians tend to be populists even in technical issues. To this end, Mugyenyi approves the use of technical experts even if this is disapproved by the populace. The citizen trusts the elected leader to think through, formulate and implement the development agenda. A democracy allows the political leader to experiment even without a basis for that experiment. The important thing is that the political leader will be judged favourably or otherwise at the end of the elective term.

Technocrats, on the other hand, operate on the basis of knowledge and skills; but technocrats need a society that recognizes merit. Today, Africa's societal demands are postindustrial in nature, but with a pre-industrial political leadership. In a postindustrial environment, the society defines a common core of its problems and how 
these will be confronted (Bell 1987, 60). This implies that the society needs an axial where political authority is located. When the electorate determines the course of policy action through a variety of pledges given by the various aspirants, the elected politician has no option but to engage the technocrats. Gendron $(1977,46)$ takes a historical perspective in locating the basis for political obligation. He urges that the agrarian society provided land as the basis for political power, the industrial age had capital such as machinery, while the post industrial society has human skills (human capital).

In the light of the foregoing discussion, it seems evident that whereas the claims of theoretical democracy are appealing and humane, ignoring the role of the technocrat in charting the path of development presents a problem - the lack of vital knowledge for designing sound development blueprints, and the knowhow for implementing them. We are hereby suggesting that it is in fact democratic leaders, both in theory and practice, who assume that the general citizenry is ignorant of what they want, is uneducated and would mess up the state structures. Thus, political elitism which does not want to recognize the limits of their skills is the obstacle to development. Below we identify the principle areas in which populism clashes with science.

1. Locus of Policy Decisions. Political leadership refuses to listen to advice from technocrats if in the process democracy is perceived as useless, inefficient, thereby making democratic leaders unpopular or having technocrats seem to be achievers. However practicable decisions might seem, they must either meet the political democratic test or fail to see the light of day.

2. Practicable but Unpopular policies. Following 1 above, policy decisions formulated by the technocrat may be sound but unpopular.

3. Technically Inadequate but Popular Policies. Conversely, decisions may be unsound from a technical point of view, but very popular. These are likely to be implemented because of their short term benefits to the politicians, even if in the long run they destroy social institutions. 
4. The Fear of Technology. Technology disrupts the status quo. It comes with new values that lead to a demand for new structures and institutions. The new structures may even bring in the unexpected, and in the short term there may be real challenges, but major benefits may accrue in the long term. Thus, overall, the new values improve the quality of life, but political leadership is concerned with the here and now, not the unseen future. They are concerned with fulfilling the election pledges, and so contrast sharply with the technocrats who look at the short and long term results regardless of who benefits.

5. Traditional values vis-à-vis Modernity. Technocrats focus on knowledge based solutions to problems utilizing insights from science and technology. This tends to run contrary to what is known and available. To ward off the technocratic challenges, the political leader brands the technocrat an agent of foreign ideas and values, and claims that this new knowledge is contrary to the cherished African values bequeathed to us by our forefathers. This argument sounds very patriotic to the citizenry. Yet the technocrat has no platform from which to explain his position.

\section{Conclusion}

In every instance, the nature of a decision reflects a value. For example, if a democracy were to value trust, then the leadership needs to take decisions that allow it to display and experience trust. Value-based decision making is not reliant upon predetermined reasoning based on past experiences. Instead, it is essentially a forward-looking process which asks the question, "How can I respond to this situation in such a way that I am able to express my most deeply held values?"

What technocracy aims for is not the assimilation of democratic institutions, but rather the total transformation of constitutionalism, entailing the introduction of knowledge-based means of assessing the desired development needs, aligning them to available resources, and mainstreaming these in a future value oriented thinking and policy decision making. The technocrat seeks to inform, assess and integrate the infrastructure in a merit-based management system. This is the future for African development. 


\section{References}

Agarwal, N.N. et. al. 1993. Principles of Political Science, 14th ed. New Delhi: R. Chand and Co.

Alford, R andR. Friedland. 1985. Powers of Theory: Capitalism, the State and Democracy. Cambridge: Cambridge University Press.

Bell, Daniel. 1973. The Coming of Post - Industrial Society. New York: Basic Books.

--. 1987. "The Post-Industrial Society: A Conceptual Schema". Cawkell, E.A. ed. Evolution of an Information Society. London: Aslib.

Dahl, Robert. 1989. Democracy and its critics. New Haven: Yale University Press.

Dunn, John. 1994. Democracy: The Unfinished Journey: 508BC-1993AD. Oxford: Oxford University Press.

Gendron, B. 1977. Technology and the Human Condition. New York: St. Martin's Press.

Golden, Daniel. 2006. The Price of Admission: How America's Ruling Class Buys its Way into Elite Colleges- And Who gets left Outside the Gates. New York: Crown Publishers.

Howard, P. Segal. 2005. "Technological Utopianism and the Development of Modern American Society". Technological Utopianism in American Culture. Syracuse: Syracuse University Press.

Hubbert, M. King. 1974. "On the Nature of Growth". National Energy Conservation Policy Act of 1974, Hearings before the Subcommittee on the Environment of the committee on Interior and Insular Affairs House of Representatives. June 6, 1974. www.oilcrisis.com/hubbert/growth

Kurt, A. Raaflaub et al. 2007. Origin of Democracy in Ancient Greece. N.P.: University of California press.

Mugyenyi, O.M. 1987. "Development First, Democracy Second: A Commitment on Minimalist Democracy". Oyugi, W and Gitonga, A. eds. Democratic Theory and Practice in Africa. Nairobi: Heinemann.

Njalsson, Gunnar K. 2006. "From autonomous to socially conceived technology: toward a causal, intentional and systematic analysis of interests and elites in public technology policy". Theoria: A Journal of Political Theory, 108, pp.5681.

Oyugi, W andA. Gitonga eds. 1987. Democratic Theory and Practice in Africa. Nairobi: Heinemann.

Rose, R.S. 2006. The Unpast: Elite Violence and Social Control in Brazil, 1954-2002. Athens: Ohio University Press.

Sachs, Jeffrey D. 2005. The End of Poverty: Economic Possibilities for Our Time. Columbia: Penguin.

Smyth, William Henry. 1919. "Technocracy: Ways and Means to Gain Industrial Democracy". Journal of Industrial Management, 57.

Wanyande, P. 1987. "Democracy and the One-Party State: The African Experience." In Oyugi, W andA. Gitonga eds. 1987.

Wallace, Andrew. 2007. Technocracy: Building a New Sustainable Society for a Post-Carbon World. New York: NET Publications. 
Weinberg, A.M. 1976. "Can Technology Replace Social Engineering?" Teich, Albert H. ed. Technology and Man's Future, 2nd ed. New York: Philosophical Library.

Wikipedia .2009. Technocracy (bureaucratic).

http://www.tiki.maxiorek.pl/en/wiki/Technocracy_(bureaucratic).html 